\title{
A Study of Alienation in Toni Morrison's Sula: Passive Patriarchy, Marriage and
}

\section{Female Friendship}

\author{
* Dr. Shabeer Ahmad, Assistant Professor \\ ** Muhammad Ilyas Mahmood, Director (Corresponding Author) \\ *** Sajid Abbas, Visiting Lecturer
}

\begin{abstract}
This paper discusses the theme of alienation and female friendship in black women in Toni Morrison's fiction. The female bonding is a possible way to deal with alienation which is caused by various factors as racial and social discriminations. This female bonding provides back women necessary support for mutual growth and assists them in combating various social pressures. However, it is argued here that this female friendship of black women in Morrison suffers from alienation in the long run. While foregrounding the healing power of female bonding which may allow women to survive under exploitation of various kinds, this paper brings for an argument that this female companionship nevertheless is corrupted by the power of explicit or implicit patriarchal forces working under the umbrella of social institutions of class and marriage. Hence the black women need to be on guard against all those forces which endanger the consistency of their mutual companionship.
\end{abstract}

Keywords: $\quad$ Alienation, Black Women, Class Issue, Female Bonding, Marriage

\section{Introduction}

Toni Morrison (1931-2019) was an established black fiction writer and the first African American Nobel Laureate for literature who wrote ten well-read novels. Her rise to national and global recognition is attributed not only to her unique treatment of the black subjectivity but also to the "universality" of her writings. Studies dealing with her writing reveal a wide range of critical positions and theoretical perspectives: racism and African American studies, class difference and Marxist approaches, comparative literature, and psychological explorations of her work. The present study brings into analysis the Marxist theme of alienation in Morrison's second novel Sula published in 1973 for exploring the linkage of alienation with the female friendship of black women.

Alienation is a familiar topic when it comes to the discussion of modernist/ postmodernist literature, but critics seem to have paid insufficient attention to its effect in literature. The classical writers as Homer and William Shakespeare and modernist writers as James Joyce, T. S. Eliot, and Albert Camus have touched upon alienation, and therefore alienation is a universal literary theme running through different ages. This study probes into Morrison's focus on the theme of alienation and her consistent projection of alienated characters in her fiction. It is emphasized here that the concept of alienation, properly understood, can provide vital insights into the existence of African Americans via Toni Morrison's fiction.

Alienation refers to the situation when a person feels as "alien" or detached from himself, from others, from his work, and products of his creation. Alienation is defined in different ways in philosophy and social sciences and appears in different terms in literature, such as estrangement, isolation, and detachment. In this study, it is linked with the theme of female friendship in black women in Morrison's fiction.

Women's friends provide moral support and care for each other beyond the concern for self or family. It is an effort to help each other. Morrison presents such a relationship in her novels such as Sula, Love, and Paradise where the women characters build connections of various kinds among

\footnotetext{
* Department of English, University of Sahiwal, Punjab, Pakistan Email: shabbirahmad@ uosahiwal.edu.pk

** Centre for English Language \& Learning, University of Okara, Punjab, Pakistan

Email: ilyas.tsl.edu@gmail.com

*** Centre for English Language \& Learning, University of Okara, Punjab, Pakistan
} 
themselves in these novels. Here the focus of this study is female friendship in Morrison's novel Sula where Nel and Sula form a bond that makes them flourish. However, such sisterhood tends to dissipate and gives way to new tensions and conflicts. The female friendship in Morrison therefore involves two phases. First, female friendship starts and develops in response to outside pressures, and then this friendship suffers setbacks and the result is an emergent alienation.

\section{Theoretical Framework and Method of Study}

This study is based on the theory of alienation and the concept of female friendship. According to Erick Fromm, alienation is an experience in which "the person experiences himself as alien, one might say, estranged" from other relations and associations (Fromm, 1990, p.120-21). The concept of alienation has been mainly discussed in philosophy, psychology, sociology, art, and literature. In the 19th century, it was prominently "noticed by philosophers" (Murchland, 1969, p. 432). Georg Wilhelm Friedrich Hegel (1770-1831) was the first philosopher who used and developed a philosophical understanding of this term as "a separation of the mind from its essence into an alienated spirit" (Overend, 1975, p. 307). The other major theorist of alienation is Karl Marx. Differing from Hegel's idealistic exploration of the term, alienation for Marx emerges from the economic base of society: alienation of the worker from the process of work, from the product of work, from himself, and others (Marx, 1844, p. 106-120). Thus, Marx sees alienation as both a sociological process and a psychological state as alienation is created, sociologically, in the activity of working together. For the use of Marx's theory in literary analysis, Charles Reitz brings Marcuse's works into the discussion. Marcuse shifts Marxist focus on economic effects to an analysis of human factors, as for Marcuse it is not only an economic matter. "It is a matter of man as man". (Reitz, 2000, p. 7-8). Hence any activity or a relationship in which one person feels him or herself being detached or estranged from the other is an alienating activity or an alienated relationship. The current study is developed based on this theory of alienation by Marcuse for the exploration of female friendship in Mroison.

Female bonding is a very significant process in the considerations of the theorists such as Clenora Hudson-Weems, bell hooks, and Obioma Nnameka. Elizabeth Abel (1981), for instance, reflects on female friendship as a kind of bonding that gives "form, expression, and reality to how women have been for our Selves and each other" (Abel, 1981, p. 434). Female friendship, first and foremost, is a non-sexual companionship by nature based on caring for and sharing. It tends to be a public relation formed among mature females. Clenora Hudson (2004) declares this relationship among women with the purpose of "Enjoying, understanding, and supporting each other" (Hudson, 2004, p. 65). Many "critics highlight female friendship and women's solidarity" in African American literature (Dubek, 2001, p. 212) and Morrison is one of those writers who are discussed by such critics as she intends to seek, through her writings, the survival of women as subjects, not as an object, and freedom for them from patriarchal oppression by various means out of which one is the female friendship.

Morrison's texts reflect the lives of black women in America, particularly the female friendship in black women. She brings for the complexities of women relationships. Through a useful combination of characterization, settings, and plot development, her works examine black female friendship and the challenges it faces. The black women have been suffering from racial discrimination, but this issue is linked with the class issue as most black women are from the lower class, unfairly treated and appropriated in a patriarchal structure that oppresses women. She presents all issues related to female friendship and social complexities by going into the psychological depths of the women characters. Through the insightful use of characterization, setting, and plot development, her works examine black female friendship and the challenges it faces. The black women have been suffering from racial discrimination but more than that this problem is their belonging to the lower class, unfairly treated and appropriated in patriarchal structures that oppress them.

\section{Discussion: Passive Patriarchy, Marriage and Female bonding}

Female bonding suffers a setback and mostly fails in Toni Morrison's novels and changes into an estranged relationship. In Morrison's second novel Sula, the girlhood relationship between Nel and Sula no longer remains stable in adulthood. Despite the strength and intensity of friendship between the two girls during their adult time, their mutual bond disintegrates as they grow mature. Here, patriarchal structures of race, class, and marriage threaten the female bonding, overcome its nurturing quality, and eventually destroy it. Morrison uses this ultimate failure to warn black women of their 
lack of trust in each other by reminding them of the destructive power of patriarchy with an overwhelmingly negative impact on them. The major factor of estrangement in Sula and Nel's friendship is the marriage of Nel with Jude, which is connected with race and class as per the current analysis. Further, Sula is also a real example of the pains of intra-racial discrimination as she is always considered an outcast of society by the people of her black community. She is the victim of endless marginalization which is the result of her strong refusal of the certain restrictions of black society. Sula is also the best instance of the effects of oppressive white supremacy on black people and the description of the corrupt white forces which compel the black people to be alienated from the members of their society.

In Sula, there is no strong male figure but there is present "passive patriarchy" which is a term used by Susan Mayberry (2003 526) and Kadidia Sy (2008 47), which signifies a type of patriarchy in which "men are not simply portrayed as conscious oppressors of women" (Sy, 2008, p. 47). In such a case, men suffer, unconsciously, from a certain bias existent in the structures of racism and class. However, other than Jude, there are other passive male characters too in this novel. Apart from the absent characters like Sula's dead father, Boy Boy (Eva's husband), Plum and Tar Baby also are such passive males. Ajax is a gracious male, however, he also faces racial discrimination because of his skin color. Then there is Shadrack, a victim of another patriarchal institution -- war. Suffering from the traumatic stress of World War II, Shadrack faces a mental rupture. Susan Mayberry identifies Jude as an embodiment of passivity who is used by Sula. "Jude is one of the most passive male figures in Sula" (Mayberry, 2003, p. 526). Jude's sense of insecurity qualifies him as passive, submitting himself to the strong impact of racial and class oppressiveness that pushes him to an early marriage with Nel.

Jude becomes a target of racism and after being denied employment, his all dreams fall apart. "He stood in lines for six days" and the reply was "Come back tomorrow" (Morrison, 1973, p.82). Jude is suffering from racial discrimination that does not allow black people to enter the workforce. The narrator narrates Jude's desire for work, “... his feet wanted the heavy work shoes" (ibid, 81-2). $\mathrm{He}$ desires a job in the construction sector so that he can reclaim his manhood damaged by the light duties. The description of Jude portrays the agony of the all-black people in that society. The inability to find a job hurts him as a man. As Cedric Gael Bryant points out that for the people like Jude and other similar persons, "manhood and self-worth are bound with work (Bryant, 1990, p. 735)". In his daydreaming, Jude keeps on thinking of finding a noble kind of work to glorify his humanity. The reality, however, reduces him into a shadow of himself as he is unable to get the job. Losing the job entails Jude's deprivations and failures in social mobility which causes him to lose any sense of self.

While racism and class consciousness defeat Jude, he tries to seek shelter in another patriarchal institution, marriage, which he desires would ultimately provide means to resolve his problems, to redeem his manhood and confidence in life. Shari Coulis notes, "Jude marries Nel when his hopes of proving his masculinity fade" (Coulis, 2003, p. 7). In a sense, Jude marries Nel for soothing his pain and securing his manhood. Although he enters into marriage to manage his griefs, marriage does not work the miracle he wishfully hopes. "Passive patriarchy" is clear output here, because, Jude marries for facing the challenges that racial injustice imposes on him. This union (marriage) is of alienating nature for Nel as well, especially in the matter of her friendship with Sula. Ready to help Jude who is suffering from a deep emotional crisis, Nel accepts his marriage proposal. She provides Jude with care and emotional assistance but Jude's sense of insecurity only increases which ultimately leads to Jude's disloyalty with Nel and results in his discarding of the illusions created by his marriage with Nel. Jude's infidelity brings this marriage to an end under a socioeconomic scenario created by the patriarchal institutions of class and race.

Jude's victimization, under the forces of the institutions of race and class, has a damaging effect on Nel too. Maureen Reddy comments on the challenge Nel has faced and the prejudices she has lived through all because of the "imposed limitations on black women's lives" (Reddy, 2000, p. 4). The major setback originates from the alienated relation in her marriage with Jude; "Marriage for Jude and Nel is mutually self-denying" (Mayberry, 2003, p. 526); "The union is made because Nel is a tool for Jude's ego" (Bakerman, 1992, p. 552). The more Jude works to make progress in his individuality the more he makes Nel deprived of hers in his struggle to be a strong man but of no avail. 
Marriage causes two forms of alienation in this novel: alienation in husband and wife and then between the two female friends, Sula and Nel. The major output of this wrongly developed relationship is the loss of "Jude and Nel's previous sense of themselves" (Christian, 1993, p. 82). Thus, Nel devalues her friendship with Sula that used to be a source of fighting against various patriarchal and racist abuses. The marriage cannot alleviate the damage racist politics and patriarchal structures have caused for Jude. Morrison seems to bring into focus the strategy of the two girls whose identity with one another is gone to the overprotectiveness of heterosexual interactions. On one hand, Nel abides by the outdated beliefs of society but on the other hand, Sula is the rebellious explorer. Sula and Nel's union and mutual approval denote a psychic harmony but it breaks after Nel's marriage with Jude. Sula and Nel destroy their friendship by their involvement in heterosexuality which entails Nel's inner death and Sula's actual death.

Sula is the central female character who fights her black community for a life of her own will, a life of freedom and liberty. She desires a life of forever friendship with Nel, which when not allowed forces her to keep on wandering like a vagabond after Nel's marriage, as her best friend's marriage creates a gap in her life that could not be fulfilled by any other person or relation. Sula is represented as an outsider in the novel which can be seen as Morrison's response to the black literature about men that confines to journeys or flights to men only who go from place to place or lookout and over and beyond and so on. Sula appears as a character that chooses her path, leaves the traditional life and gender roles, and instead follows the ways that are commonly connected with men. Morrison states: "She picks up a man, drops a man" (Morrison, 1973, p.392).

This masculine and adventurous nature of Sula brings to mind Susan Neal Mayberry's work "An Elegy on Black Masculinity: The Beautiful Boys in Sula" of her book Can't I Love What I Criticize: The Masculine in Morrison (2007), where she identifies three main masculine models: passive, adventuresome, and mad. Jude is the representative of the passive model who is more reflective and less practical; the adventuresome is seen in Ajax who forces Sula to have affair; and the mad one in Shadrack who fixes a day to be celebrated as National Suicide Day. Understanding the above types of patriarchy and confrontations in Sula's mind about them helps understand the problem of gender discrimination in African Americans (Mayberry, 2007, p.51-70).

Sula is absent for ten years from Medallion trying hard to find love and the "same language of love "(Morrison, 1973, p.120). As a refugee and stranger, she remains on the margin of all borders. She discovers that "a lover was not a companion and could never be - for a woman" (ibid. 121). Through this projection, Morrison draws a comparison of a male lover and a female friend to make her readers realize the importance of female friendship. Sula gets a realization that she can't find love and a friend like Nel and so continues to live in her world in alienation from all around. While her loneliness assumes the absence of other people, the solitude she faces creates no room for interaction with others. Finally, Sula expires loneliness. At that moment Sula has the retention of friendship with Nel as both are "two throats and one eye" (ibid. 147). After death, Sula has only one wish to tell Nel: "dying isn't so bad" (ibid.147). Sula's body was portrayed as both bird and water. Like birds, dying is eminent by flapping of doves, and like water; she drops her previous dreams into the gloominess of water. "She had no center, no speck around which to grow". "And like any artist with no art form, she became dangerous" (ibid.121). She feels she is torn between the silent and the spoken. At her death bed when Nel comes to see her, the silence of Sula is an emblem of "speaking the unspeakable". The young Sula possesses two lives, two halves, the social and the solitary, an individual and a daughter, and such contradictory pressures made her feel incapable of flight.

Accustomed to getting whatever she wants, Sula seems to take her affair with Jude just as another whim. Like in The Bluest Eye, Sula's character highlights a point that "the parents should not fail in fostering daughters"(Ahmad, S., et al,2020,p.120) Answering Eva's advice about having children, Sula responds that she has no mindset of making anybody else. "I want to make myself" (Morrison, 1973, p. 92). This lifelong project of "making" herself turns her into an outcast. Sula, thus, loses her lifetime and only friend in her possession. Sula decides to leave the Bottom right after Nel's decision to marry. After this, Sula is engaged in a self-building plan throughout her life. "To Sula, however, being a wife and a mother are not pre-requisites for selfhood" (Galehouse, 1999, p. 352); and "Her journey is the enactment of that freedom" (Stein, 2000, p. 54). This self-centeredness also becomes a reason for the failure of friendship. 
Thus, this novel brings for the primacy of female bonding over romantic love and supports the idea of female friendship as a means for security and comfort. Sula's death serves as a final call for the need for friendship between the two females for counteracting the patriarchal forces and structures. Nel is completely shattered after the death of her female friend Sula. Through Nel's reading of the great importance of female friendship, Morrison gives an understanding that marriage is a "risky fulfillment for women" (Demetrakopoulos, 1987, p. 135). Morrison brings into inquiry the primacy of marriage in women's lives and sets Nel's failure as an example to guide women that other things as female friendship and professional career are equally or more important tasks for a woman. Through Nel, Morrison is asking black women to think twice before engaging themselves in such institutions that oppress them.

If Nel does not become successful in making herself complete through marriage, Sula does not succeed in substituting independence for female friendship and dies alone. From Sula's point of view, her friendship with Nel starts declining when Nel undergoes a married relationship with Jude. The marriage exerts a fast gear to Sula's departure and for ten years she stays away from the Bottom. Sula cannot share with other members of the female community an important quality which bell hooks calls "love", "no one can destroy our integrity as women who love" (hooks, 2002, p. 137). Female friendship demands selflessness and sacrifice for others which Sula does not prove to be doing.

Nel is brought up to be traditional by her mother, Helen. From her childhood, Nel has no opportunity to create imaginations in her mind, "Any enthusiasms that little Nel showed were calmed by her mother" (Morrison, 1973, p 18). Nel has no chance and guts to show rebellion. She notices the traces of racism when she sees her mother Helene disgraced by the white people on the train. A white man calls Nel's mother a 'gal when she falsely goes into his car on the train. Helen does not reply but her trembling hands betray her fear and weakness. Helene is aware of the cruelty of white racism but she chooses to become subservient. This action and reaction that $\mathrm{Nel}$ is unable to understand motivate scornful stares from the black soldiers in the train who make fun of Nel's mother. At this moment, Nel undergoes a thoughtful resolve "to be on guard-always" (ibid.22). At this point, she makes up her mind to keep a distance from her mother. After this incident, Nel decides to live a dispersed life from her mother. Nel sees her grandmother differently from her mother, though. While Nel's mother, Helene, is a "Creole Whore" (ibid.17), Nel's grandmother feels good as she meets Nel in a yellow dress, the bird-like outfit proposing a voyage from a conformism that suggests a world different from the one her mother has enforced upon her. Nel does not want to endorse the values of her mother, Helene. After returning from her journey, Nel realizes: "I am me. I am me" (ibid.25).

This awareness enables Nel to form a bond with Sula. When Nel goes across to Sula she doesn't wants to pull her nose as her mother has taught her, "smooth hair -- no longer interested her" (ibid.51). Full of loving men and women Sula's house is opposite to Nel's world. This type of opposition enables them to develop a relationship of friendship and through their friendship, they both try to end their isolation. The dreams of Sula and Nel are opposite to each other, however. Nel, like Pauline Breedlove in The Bluest Eye, desires to be loved at an extreme level of love: "Someone as interested as she in the flow of her imagined hairs" (ibid.51). Nel has dreamed of a prince who never reaches, but she expects "smiling sympathetic eyes" that can distinguish her existence. Sula as a friend is available for her but the princely man never comes to end her isolation and alienation. Nel in her dreams longs for a man but he always remains farther away in her dreams than Sula who remains the center of her imagination. Sula and Nel both want to have a man to guard and cherish their thoughts. The combination of their opposing characters in friendship disturbs their "noon dreams" and comforts their isolation, and both fight back against integration.

Morrison disrupts the adapted notion that friends "lean on each other" by advocating, as an alternative, "using each other to grow on". The friendship of Sula and Nel is insubordinate and this becomes clear when both discover an emotive closeness. This closeness doesn't develop with anyone else or even with their mothers. Sula and Nel, being fully aware of the unsatisfactory relation between their mothers and themselves, forcefully think that "there was something else to be" above and beyond whites and males. Morrison attacks the brutal ideas of love that include dreadful sights of home fighting and hollow love as portrayed in her novels as The Bluest Eye and Sula. In Sula, there is the strong and memorable character of Eva who was forced to nourish her family with one leg. Eva refuses to be converted into a domestic female like other black females and proves to be an 
independent young African woman. The mothers, in this novel, are not in a harmonious relationship with their daughters. Sula and Nel have a distant and weak bond with their mothers. Like Pecola Breedlove in The Bluest Eye, both Sula and Nel are deprived of their mother's love and have experienced alienation wherever they go or stay. Many of Morrison's characters seek to relieve their "mother hunger" by forming attachments to other individuals. However, ironically, they fail in creating such kinship bonds that could soothe their mother's hunger and make them get out of alienation. Thus the alienated mother-daughter relation not only leads to alienated gender relations but also alienated female friendship. Such characters suffer estrangement of one sort or another throughout their lives.

If Sula's self-building plan remains unsuccessful, Nel's lack of self-knowledge also goes for long unless she meets with Eva, who shatters her illusions and makes her find out the meaning of her companionship with her friend. The meeting proves to be important for Nel, who gets an understanding of the strength of her girlhood friendship with Sula. By undergoing a thought process, she realizes the blunders she has made and gets a new degree of understanding, "it is Sula who leads her to it" (Reddy, 2000, p. 10). Through the epiphany Nel comes to a realization of her friendship with Sula, "all that time, I thought I was missing Jude. ...O Lord, Sula, she cried, girl, girl, girl girl girl. It was a fine cry" (Morrison, 1973 p. 174). She regrets the misunderstanding and the ensuing differences between them that lead to their alienation from each other. This cry is a commentary on her girlhood relationship with Sula and the nurturing value attached to this companionship. Axel Nissen opines: "Conventional morality blocks Nel's realization" of loss of friendship with Sula (Nissen, 1999, p. 271). Nel fails to understand that friendship requires understanding, forgiveness, and open-heartedness. However, this late understanding is still significant as Nel's final realization may help her live an improved life with a better understanding of various challenges of life for the black women in America. This is obviously what Morrison encourages black women to do.

Even though Morrison wanted to support and guide women for making sincere assurance to female friendship, what she portrays in Sula is failed sisterhood. In one sense, it is patriarchy that interferes with this true genuine sisterhood and brings it to an end as Spillers observes, "In the relationship between Nel and Sula, Morrison demonstrates the female's rites-of-passage" (Spillers, 1983, p. 68). Yet Morrison paints a gloomy picture by the end since the friendship between Sula and Nel fails. Through the failure, Morrison brings to the fore various challenges faced by female bonding and warns women against the dangerous power of patriarchal structures. Nel and Sula have not been taking care of their friendship from the attacks of patriarchy, and they end up paying a high price. Through the portrayal of both characters, the reader is in a position to understand the loss of female friendship and the existence of everlasting alienation as the outcome. Problems occur when both Sula and Nel stop seeing each other properly: while Sula engages in building self to the extent of overlooking others, Nel spends her time trying to uplift Jude and therefore becomes too other-focused. Morrison expects her readers to avoid making such mistakes and wants them to be aware that class and marriage are two patriarchal structures (institutions) responsible for alienation in women bonding.

\section{Conclusion}

The common experience of the black women urges them to form mutual bonds to deal with their problems such as to satisfy their mother hunger, deal with their problematic past, and fight against discrimination based on race, class, and gender. Female friendship not only helps women counterbalance the effects of patriarchy but also provides them with a sense of independence. However, this study of Morrison's novel Sula highlights the omnipresent destructive power of patriarchal institutions such as class and marriage and warns women of the danger that these institutions pose to their mutual bonds. Furthermore, this study of female friendship under the theoretical framework of Alienation theory invites more studies on this subject especially under the umbrella of comparative literature. Thus, the works of Pakistani and Indian female writers can be analyzed by bringing them into comparison with Morrison's fiction while exploring the theme of alienation and female friendship in these works.

\section{References}

Abel, Elizabeth. (1981). (E) Merging Identities: The Dynamics of Female Friendships in Contemporary Fiction by Women. Signs: Journal of Women in Culture and Society, 6, 41335. 
Ahmad, Shabbir. et. al. (2020).Parental Hunger and Alienation in Toni Morrison's The Bluest Eye, International Review of Literary Studies, 2.1, pp. 22-31

Bakerman, Jane. (1992). "The Seams Can't Show an Interview with Toni Morrison." Conversation with Toni Morrison. Ed. Danielle Taylor-Guthrie. San Francisco: California Newsreel, 30-42.

Bryant, Cedric Gael. (1990). "The Orderliness of Disorder: Madness and Evil in Toni Morrison's Sula." Black American Literature Forum, 24, 731-45.

Christian, Barbara T. (1993). "Layered Rhythms: Virginia Woolf and Toni Morrison." Modern Fiction Studies, 39.3-4, 483-500.

Coulis, Shari. (2003). "The Impossibility of Choice: Gender and Genre in Mariama Bâ's So Long a Letter". Emerging Perspectives on Mariama Bâ: Postcolonialism, Feminism, and Postmodernism. Ed. Ada Uzoamaka Azodo. Trenton: Africa World P.

Demertrakopoulos, Stephanie A. (1987). "Morrison's Creation of a White World: Tar Baby and Irreconcilable Polarities." New Dimensions of Spirituality: a Biracial and Bicultural Readings of the Novels of Toni Morrison. Karla F. C. Holloway and Stephanie A. Demertrakopoulos. Westport, Conn: Greenwood, 131-142.

Dubek, Laura. (2001). "Lessons in Solidarity: Buchi Emecheta and Mariama Bâ on Female Victim (izer) s". Women's Studies, 30, 199-224.

Fromm, Erich. Marx's concept of man.New York: Frederick Ungar Publishing, 1961

Galehouse, Maggie. (1999). "New World Woman: Toni Morrison's Sula." Papers on Language and Literature, 35, 339-63.

Hegel, F. W.G. The Phenomenology of Mind. Trans. J. B. Baillie. New York: The Macmillan, 1931

Hooks, bell. (2002). Communion: The Female Search for Love. New York: William Morrow

Hudson-Weems, Clenora. (2004). Africana Womanist Literary Theory: A sequel to Africana Womanism: Reclaiming Ourselves. Trenton: Africa World P.

Marx, Karl. Economic \& Philosophic Manuscripts of 1844.New York: Prometheus Books, 1932:106120

Murchland, B. "Some Comments on Alienation". Philosophy and Phenomenological Research 29(3) 1969: 432-438

Mayberry, Susan Neal. (2007). "An Elegy on Black Masculinity: The Beautiful Boys in Sula." In Can't I Love What I Criticize? The Masculine and Morrison, 51-70. Athens; London: University of Georgia Press

Morrison, Toni. (1970). the Bluest Eye. New York: Pocket Books .. (1973). Sula. New York: Plume

Nissen, Axel. (1999). "Form Matters: Toni Morrison's 'Sula' and the Ethics of Narrative." Contemporary Literature, 40(2), 263-285

Overend, T. "Alienation: A Conceptual Analysis." Philosophy and Phenomenological Research 35(3) 1975: 306-320

Reddy, Maureen T. (2000). "The Tripled Plot and Center of Sula." Understanding Toni Morrison's Beloved and Sula: Selected Essays and Criticisms of the Works by the Nobel Prizewinning Author. Ed. Solomon O. Iyasere and Marla W. Iyasere. Troy: Whitston, 1-18.

Reitz, Charles. Art, alienation, and the humanities: a critical engagement with Herbert Marcuse. New York: State University of New York Press, 2000:7-8

Spillers, Hortense J. (1983). “A Hateful Passion, a Lost Love.” Feminist Studies, 9, 293-323.

Sy, Kadidia, (2008). "Women's Relationships: Female Friendship in Toni Morrison's Sula and Love, Mariama Ba's So Long a Letter and Sefi Atta's Everything Good Will Come". English Dissertations. (http://digitalarchive.gsu.edu/english_diss)

Stein, Karen F. (2000). "Toni Morrison's Sula: A Black Woman's Epic." Understanding Toni Morrison's Beloved and Sula: Selected Essays and Criticisms of the Works by the Nobel Prize-winning author. Ed. Solomon O. Iyasere and Marla W. Iyasere. Troy: Whitston, 49-60. 